DOI: $10.21608 / z v j z .2017 .29250$.

\title{
Toxicological Effects on Silver Nanoparticles as Anticarcinogenic Agent and its Treatment with Curcumin
}

\author{
Magdy F. Abou El-Fotoh*, Ali H. Abou Hadeed, Esraa K.G. Kotb \\ Forensic Medicine and Toxicology Department, Faculty of Veterinary Medicine, Zagazig \\ University, Egypt
}

\begin{abstract}
In this study, the efficacy of silver nanoparticles (AgNPs) for treatment the Ehrlich Ascites Carcinoma cells (EAC) and trials to overcome its side effects by administration of the curcumin were carried out. Hundred and fifty mature male albino mice were divided into fifteen equal groups. Negative control animals were I.P injected with sterile normal saline, Positive control: oral dose curcumin daily an oral dose of $(400 \mathrm{mg} / \mathrm{Kg} \mathrm{BW})$, suspended in dist. $\mathrm{H}_{2} \mathrm{O}$ dosed, in the induced cancer control group: mice were inoculated with EAC through serial I/P of $2.5 \times 10^{6}$ EAC tumor cells $0.2 \mathrm{ml}$ at 5-8 days intervals. Inject I.P. with different doses of silver nanoparticles, $100 \mu$ AgNPs+induced tumor, $200 \mu$ of AgNPs + tumor induction, $100 \mu$ AgNPs+ curcumin $(400 \mathrm{mg} / \mathrm{kg})+$ tumor induction, $200 \mu \mathrm{AgNPs}+$ curcumin $(400 \mathrm{mg} / \mathrm{kg})+$ tumor induction, $100 \mu$ AgNPs before tumor induction by 15 days , $200 \mu$ AgNPs buffer tumor induction 15 days then tumor induction EAC, $100 \mu$ AgNPs + curcumin $400 \mu \mathrm{M} / \mathrm{kg}$ b.wt.) before induced tumor 15 days then induced tumor EAC, $200 \mu$ AgNPs + curcumin $400 \mathrm{mg} / \mathrm{kg}$ bw.t) before induced tumor then tumor induction EAC, $100 \mu$ AgNPs after tumor cell implantation 8 days later, $200 \mu$ AgNPs after tumor cell implantation 8 days later, $100 \mu$ AgNPs + curcumin $400 \mathrm{mg} / \mathrm{kg} \mathrm{BW}$ ) after tumor induction 8 day and $200 \mu \mathrm{AgNPs}+$ curcumin 400 $\mathrm{mg} / \mathrm{kg}$ bw.t) after 8 days tumor induction. All results and histopathologyfindings validated that the silver nanoparticles are good for treatment of EAC and the curcumin can overcome their side effects.
\end{abstract}

Keywords: Silver Nanoparticles, EAC Cancer Cells, Curcumin

\section{Introduction}

Nanotechnology is emerging as a rapidly growing field with its application in science and technology for the purpose of manufacturing new materials like cosmetics, information and communication technology (ICT), food and feed, environmental health and agricultural productions at the nanoscale level [1]. The term Nanotechnology was coined by Professor Norio Taniguchi in Tokyo Science University in the year 1974 to explain precision manufacturing of materials at the nanometer level. Nanotechnology as a branch of science which is related to nano-materials helps in overcoming the limitations of size and can change the outlook of the world regarding science [2]. By manipulating materials at the atomic level, nanotechnology offers to achieve unique properties for various desired applications. It is noticeable that most of the nature's creations occur at the nanoscale regime too [3]. Because of its widespread application, the commercial nanotechnology industry is predicted to increase significantly [4].
The term "Nano" is a Greek word synonymous to dwarf meaning extremely small [5] which is used to indicate one billionth of a meter or $10^{-}$ ${ }^{9}$. One of the most natural questions to ask when starting to deal with nanoparticles is: "why are nanoparticles so interesting"? The answer lies in the nature of and unique properties possessed by nanostructures [6]. Nanoparticles are clusters of atoms in the size range of 1-100 $\mathrm{nm}[7]$. Reducing the particle size of materials is an efficient and reliable tool for increasing their biocompatibility. Furthermore, nano-materials can be changed for more efficient applications in different fields such as bioscience and medicine[2]. Among the commercially available nano-sized materials, silver nanoparticles are by far the most used nano-compounds [8].

Silver was known only as a metal until the recent advent of the nanotechnology era, when it became recognized that silver could be produced at the nano-scale using recent engineering technologies. Silver nanoparticles 
(AgNPs) have emerged as an arch product from the field of nanotechnology. Toxicological information on nanoparticles remains insufficient; thus frameworks for future toxicological assessments on nano-sized materials have been promoted [9].

Recent studies suggest that excessive production of reactive oxygen species (ROS) and oxidative stress could be one of the possible mechanisms of nanoparticle toxicity [4]. AgNPs were reported to act via reactive oxygen species (ROS) production and glutathione depletion in mice liver cells [10]. ROS generation has been shown to play an important role in apoptosis induced by treatment with AgNPs [11]. ROS in general cause DNA damage, including a multitude of oxidized base lesions, a basic site, single and double-strand breaks; all of these can be cytotoxic, genotoxic or mutagenic [12]. There are few conventional drugs that can stimulate liver function and offer hepato-protection or help in the regeneration of hepatic cells [13]. Many plant derived natural products have the potential to be hepatoprotective and therefore can be used to treat acute and chronic liver diseases. The challenge is to identify the most promising compounds and evaluate their protective mechanism [14].

Curcumin is a widely used spice and coloring agent in food. It is extracted from the powdered dry rhizome of turmeric (Curcuma longa L.), a perennial herb widely cultivated in tropical regions of Asia. Curcumin is known to have multiple pharmacological properties such as anti-carcinogenic, anti-inflammatory and antioxidant [15]. However, the preventive potential of curcumin against nanoparticles toxicity has not been explored. This study was designed to investigate AgNPs induced cytotoxicity, oxidative stress and apoptosis in mice and evaluate if silver nanoparticles exhibit toxic effects on the liver following intraperitoneal infection. The preventive potential of curcumin against AgNPs induced toxicity was further examined.

Cancer is the second leading cause of death in developing countries as it presently responsible for about $25 \%$ of deaths in developed countries and for $15 \%$ of all deaths worldwide. It can therefore be considered as one of the foremost health problems, with about 1.45 million new cancer cases being expected yearly, it may be caused due to incorrect diet, genetic predisposition or environmental factors [16]. Cancer chemotherapy is a very difficult task as the problems of chemotherapy are drug resistance, multidrug resistance [17] and one of its main associated another problems is the nonspecific toxicity of most anticancer drugs due to their bio-distribution throughout the body, which requires the administration of a large total dose to achieve high local concentrations in a tumor [18].

The present study aimed to investigate the in vivo hepatotoxic effects of silver nanoparticles in mice. Moreover, aimed to study the potential hepatoprotective role of the silver nanoparticles and dietary antioxidant curcumin. For this, the following parameters were analyzed: Biochemical analysis in liver tissues Include, Superoxide dismutase (SOD), Catalase (CAT), Glutathione peroxidase (GPx), Glutathione reductase (GR), Reduced glutathione (GSH) and Lipid peroxidation: Malondialdehyde (MDA), DNA fragmentation assay and Histopathological studies: Liver.

\section{Material and Methods}

\section{Experimental animals}

Hundred and fifty adult male Swiss albino mice weighted 30-40 gm. were obtained from the Laboratory Animal Housing Unit, Animal Health, Research Institute, Dokki, Cairo, Egypt. The animals were clinically healthy, kept under hygienic conditions. Housed in metal cages with hard wood shavings as bedding. They were maintained on balanced ration, water and the food were giving adlibtum throughout the experimental period. The animals were accommodated to the laboratory conditions for one week before beginning of experiment.

Tumor Cell Line: Ehrlich Ascites Carcinoma cells (EAC):

The parent line of Ehrlich Ascites Carcinoma cells was initially supplied by the National Cancer Institute, Cairo University, Egypt, and maintained in female Swiss albino mice through serial intra-peritoneal inoculation of $[E A C] 2.5 \times 10^{6}$ tumor cells $/ 0.2 \mathrm{ml}$ at $5-8$ day intervals in the laboratory in an ascites form. 
Transplantation of Tumor in mice:

EAC cells were collected from moderately growing 5-8 days old donor. After making appropriate dilution, the viability was checked by the trypan blue exclusion test $0.2 \mathrm{ml}$ portions of ascetic fluid containing $2.5^{\mathrm{X}} 10^{6}$ viable cells were intraperitoneally injected in a group of healthy mice for maintenance of the line and for experimental work [19].

\section{Silver nanoparticles}

Silver nanoparticles (AgNPs) are colloidal silver nanoparticles yellow / grey / opal colored liquid with particle size $(33 \mathrm{~nm})$ total diameter with ware length (400 $-410 \mathrm{~nm})$, molar weight $(8,93 \mathrm{E}+07)$ and molar concentration (2.32 E-10) were purchased for the International Center of nanotechnology, Sadaat University, El Sadaat City- Monifya Province, Egypt.

Curcumin: was purchased from Sigma Co. Cairo Egypt
Table 1: Experimental design

Table 1: Experimental design

1- Negative control: I.P injection with normal saline

2- Positive control: oral dose curcumin daily an oral

(400 mg/Kg B. Wt.) according to [19] suspended in 4- 100 $\mu \mathrm{M} \mathrm{AgNPs+} \mathrm{induced} \mathrm{tumor}$ dist. $\mathrm{H}_{2} \mathrm{O}$ dosed by [20].

5-200 $\mu \mathrm{M}$ of AgNPs + induced tumor

3- Induced cancer control group: mice were inoculated 6-100 $\mu \mathrm{M}$ AgNPs+ curcumin $(400 \mathrm{mg} / \mathrm{kg})+$ with EAC (Ehrlich Ascites Carcinoma cells) through induced tumor serial I/P of $2.5 \times 10^{6}$ EAC tumor cells $0.2 \mathrm{ml}$ at 5-8 7- $200 \mu \mathrm{M}$ AgNPs + curcumin $(400 \mathrm{mg} / \mathrm{kg})$ days intervals in the laboratory in an ascites form + induced tumor.

According to [21].

8- $100 \mu \mathrm{M}$ AgNPs before induced tumor 15 days then induced tumor cell.

9- $200 \mu \mathrm{M}$ AgNPs buffer induced tumor 15 days then induced tumor EAC.

10- $100 \mu \mathrm{M}$ AgNPs + curcumin $400 \mu \mathrm{M} / \mathrm{kg}$ b.wt.) before induced tumor 15 days then induced tumor EAC.

11- $200 \mu \mathrm{M}$ AgNPs + curcumin 400 $\mathrm{mg} / \mathrm{kg}$ bw.t) before induced tumor then induced tumor EAC

12- $100 \mu \mathrm{M}$ AgNPs after tumor cell implantation 8 days latter.

13-200 $\mu \mathrm{M}$ AgNPs after tumor cell implantation 8 days latter.

14- $100 \mu \mathrm{M}$ AgNPs + curcumin $400 \mathrm{mg} / \mathrm{kg}$ bw.t) after induced tumor 8 day.

15-200 $\mu \mathrm{M}$ AgNPs + curcumin $400 \mathrm{mg} / \mathrm{kg}$ bw.t) after induced tumor 8 day.

\section{Preparation of Liver Homogenate}

One gram of the liver tissue washed in distilled water then put in homogenized buffer and homogenized separately using a Dounce homogenizer at $4^{\circ} \mathrm{C}$. The crude tissue homogenate then centrifuged at $3000 \mathrm{xg}$ for 15 min at $4^{\circ} \mathrm{C}$ and the supernatant was separated and kept at $-20^{\circ} \mathrm{C}$ till estimation of malondialdehyde (MDA), reduced glutathione (GSH), glutalhione pcroxidase (GPx), glutathione reductase (OR), and catalase (CAT).

\section{Biochemical analysis}

The optical densities of the given parameters were measured by Shimudzu type spectrophotometer (UV 120-02) manufactured by Incorporation Kyoto, Japan. Include, Catalase (CAT), Glutathione peroxidase (GPx), Glutathione reductase (GR), Reduced glutathione (GSH), Lipid peroxidation and Malondialdehyde (MDA). 


\section{Histopathological studies}

Liver samples from all mice were fixed in $10 \%$ neutral buffered formalin. Then specimens were prepared for paraffin sections and stained with $\mathrm{H} \& \mathrm{E}$ for histopathological examination under light microscope [23].

\section{Statistical analysis}

The results were expressed as means \pm S.E.M. All data were done with the Statistical Package for Social Sciences (SPSS 17.0 for windows) [24]. The results were analyzed using one way analysis of variance (ANOVA) followed by Duncan's test for comparison between different treatment groups. Statistical significance was set at $\mathrm{p}<0.05$.

\section{Micronucleus test (MN)}

There was a significant increase $(\mathrm{P} \leq 0.05)$ $\mathrm{MN}$ frequencies in erythrocyte of silver nanoparticles (AgNPS) treated EAC mice compared with positive infected group. While combined treatment of curcumin and AgNPS significant decrease which non-significant in curcumin group. MDA is the end product of lipid peroxidation and has been used widely as a marker of free radical damage in lipid molecules. Peroxidation of the fatty acids results in MDA production [25]. MDA cause the crosslinking of membrane component by affecting the ion exchange through the cell membrane and change ion permeability of membrane and enzyme activities.

\section{Results and Discussion}

Table 2: Efficacy of silver Nano particles and curcumin induced micronucleus frequency in the erythrocytes blood smear of treated EAC bearing male mice.

\begin{tabular}{|c|c|c|}
\hline \multicolumn{2}{|r|}{ Groups } & MN/1000 erythrocytes \\
\hline 1 & Infected control & $6.48+1.25^{\mathrm{a}}$ \\
\hline 2 & Curcumine control & $0.75 \pm 0.06^{\mathrm{c}}$ \\
\hline 3 & AgNPS $100 \mu \mathrm{M}$ & $0.97 \pm 0.18^{b}$ \\
\hline 4 & AgNPS $200 \mu \mathrm{M}$ & $1.16 \pm 0.22^{b}$ \\
\hline 5 & EgNPS $100+$ EAC infected & $1.36 \pm 0.36^{\mathrm{c}}$ \\
\hline 6 & AgNPs $200+$ EAC infected & $0.85 \pm 0.33^{c}$ \\
\hline 7 & AgNPs+EAC infected +curcumin & $0.76 \pm 0.15^{\mathrm{c}}$ \\
\hline 8 & AgNPS $200 \mu \mathrm{M}+$ curcumin+infected EAC & $0.56 \pm 0.11^{b}$ \\
\hline 9 & AgNPS $200 \mu \mathrm{M}$ AgNPs+ before induced tumes & $0.38+0.15^{b}$ \\
\hline 10 & $\begin{array}{l}100 \mu \mathrm{M} \text { AgNPs }+ \text { curcumin } 400 \mu \mathrm{M} / \mathrm{kg} \text { b.wt.) before induced tumor } 15 \text { days then } \\
\text { induced tumor EAC. }\end{array}$ & $0.29+0.10^{\mathrm{b}}$ \\
\hline 11 & $\begin{array}{l}200 \mu \mathrm{M} \text { AgNPs + curcumin } 400 \mathrm{mg} / \mathrm{kg} \text { bw.t) before induced tumor then induced } \\
\text { tumor EAC }\end{array}$ & $0.22+0.15^{\mathrm{c}}$ \\
\hline 12 & $100 \mu \mathrm{M}$ AgNPs after tumor cell implantation 8 days latter. & $0.19+0.05^{\mathrm{c}}$ \\
\hline 13 & $200 \mu \mathrm{M}$ AgNPs after tumor cell implantation 8 days latter. & $4.25+0.45^{b}$ \\
\hline 14 & $100 \mu \mathrm{M}$ AgNPs + curcumin $400 \mathrm{mg} / \mathrm{kg}$ bw.t) after induced tumor 8 day. & $3.10+0.20^{\mathrm{b}}$ \\
\hline 15 & $200 \mu \mathrm{M}$ AgNPs + curcumin $400 \mathrm{mg} / \mathrm{kg}$ bw.t) after induced tumor 8 day. & $0.9+0.10^{\mathrm{c}}$ \\
\hline
\end{tabular}

Mean within the same column carrying different superscripts are significant $(\underline{\mathrm{P}<0.01)}$.

GSH, is formed by glutamyl cysteinyl ligas $(\gamma$-GCL) and glutathione synthetase (GSS), $\gamma$ GCL catalyses the first and the rate -limiting step in the process that yields glutamyl cysteine in cellular GSH biosynthesis. The final final step is catalyzed by GSS and adds a glycine residue to form glutamyl cysteine or glutathione [26].
Silver nanoparticles cause histopathological change in the liver, which indicated the tendency of silver ions to bind the thiol groups in livers causing reduction reactions, transferring of glutathione to bile bladder and reducing the concentration of glutathione available for biochemical reductions. it should be mentioned that reduced glutathione is necessary to remove peroxides [27]. 
Table 3: The activity of reduced glutathione (GSH) concentration (nmol/mg protein), glutathione reductase (GR) (mmol/gm hepatic tissues) and glutathione peroxidase (GPX) concentration (u/mg protein) in hepatic homogenate of mice in all groups administered silver Nanoparticles (100 or $\mu \mathrm{M})$ and curcumin against carcinogenicity of EAC cells.

\begin{tabular}{|c|c|c|c|c|}
\hline Groups & $\begin{array}{r}\begin{array}{r}\text { Antioxidant } \\
\text { enzymes }\end{array} \\
\end{array}$ & $\begin{array}{l}\text { Reduced glutathione } \\
\qquad(\mathrm{GSH})\end{array}$ & $\begin{array}{l}\text { Glutathione reeducates } \\
\qquad(\mathrm{GR})\end{array}$ & $\begin{array}{l}\text { Glutathione peroxidase } \\
\qquad(\mathrm{GPx})\end{array}$ \\
\hline & 1 & $42.75 \pm 0.44^{\mathrm{c}}$ & $18.35 \pm 0.39^{d}$ & $70.25 \pm 0.70^{c}$ \\
\hline & 2 & $70.10 \pm 1.25^{\mathrm{a}}$ & $16.80 \pm 0.42^{\mathrm{d}}$ & $15.15 \pm 0.95^{\mathrm{c}}$ \\
\hline & 3 & $98.75 \pm 5.60^{\mathrm{a}}$ & $59.10 \pm 3.40^{\mathrm{a}}$ & $122.25 \pm 5.30^{\mathrm{a}}$ \\
\hline & 4 & $45.45 \pm 1.30^{\mathrm{c}}$ & $29.25 \pm 0.40^{\mathrm{c}}$ & $92.30 \pm 3.65^{b}$ \\
\hline & 5 & $48.70 \pm 1.70^{\mathrm{c}}$ & $33.60 \pm 0.60^{\mathrm{c}}$ & $95.60 \pm 3.75^{b}$ \\
\hline & 6 & $53.90 \pm 0.35^{b}$ & $24.30 \pm 0.30^{\mathrm{d}}$ & $61.30 \pm 2.15^{b}$ \\
\hline & 7 & $55.40 \pm 0.60^{\mathrm{b}}$ & $27.50 \pm 0.52^{\mathrm{d}}$ & $64.25 \pm 2.35^{\mathrm{b}}$ \\
\hline & 8 & $40.52 \pm 0.45^{\mathrm{c}}$ & $23.90 \pm 0.25^{\mathrm{d}}$ & $60.60 \pm 1.75^{\mathrm{c}}$ \\
\hline & 9 & $43.30 \pm 0.40^{\mathrm{c}}$ & $26.60 \pm 0.45^{\mathrm{d}}$ & $63.40 \pm 1.80^{\mathrm{c}}$ \\
\hline & 10 & $37.45 \pm 0.35^{\mathrm{c}}$ & $20.80 \pm 0.30^{\mathrm{d}}$ & $58.50 \pm 1.50^{\mathrm{c}}$ \\
\hline & 11 & $41.60 \pm 0.65^{b}$ & $22.10 \pm 0.20^{\mathrm{d}}$ & $61.30 \pm 1.35^{\mathrm{c}}$ \\
\hline & 12 & $50.40 \pm 2.60^{\mathrm{a}}$ & $42.70 \pm 1.80^{b}$ & $85.60+3.15^{b}$ \\
\hline & 13 & $56.75 \pm 2.85^{\mathrm{a}}$ & $46.30 \pm 2.20^{\mathrm{b}}$ & $88.45 \pm 3.45^{\mathrm{b}}$ \\
\hline & 14 & $48.00 \pm 0.70^{\mathrm{b}}$ & $35.70 \pm 1.60^{\mathrm{c}}$ & $81.20 \pm 3.00^{\mathrm{b}}$ \\
\hline & 15 & $51.50 \pm 1.40^{\mathrm{b}}$ & $38.30 \pm 1.75^{\mathrm{c}}$ & $83.55 \pm 3.25^{\mathrm{b}}$ \\
\hline
\end{tabular}

Mean within the same column carrying different superscripts are significant $(\underline{\mathrm{P}<0.01)}$.

Reduced glutathione which works as a direct free -radical scavenger, but functions as a substrate for GPX and GST. The decrease in GSH levels might have resulted from the increased utilization by the antioxidant mechanisms. Increased activity of GSHPX and reaction catalyzed by glutathione $S$ transferase may have a role in the reduction in GSH levels in the treated cells [28].

Oxygen free radical (OFRs) scavenging enzymes respond to conditions of oxidative stress by increasing the anti-oxydative enzyme SODS, GSH-Px and catalase activities that scavenge unwanted $\mathrm{O}_{2}, \mathrm{H}_{2} \mathrm{O}_{2}$ and $-\mathrm{ROOH}$
[29]. Hepatic carcinoma, EAC implanted mices and trials by I/P injection of AgNPS in mice, has possible caused severe irritation of oxidant system in these cells [30]. The live tissue damage in high dosage of Nano-silver particles is probably caused by stimulation of the antioxidant system in these cells by Nano silver injection. Free radicals induced from Nano silver particles attack hepatocyte and cause the release of stored liver enzymes in them and enter the blood serum. Therefore, pathological changes in liver tissue might be due to the accumulation and residue of these Nanoparticles in the tissue [31]. 
Table 4: Catalase activity (U/mg Protein) and Malondialidhyde (nmol/mg protein) in mice hepatic tissues in all groups administered silver Nanoparticles $(100$ or $200 \mathrm{mg})$ and/ curcumin $(400 \mathrm{mg} / \mathrm{kg} \mathrm{b.wt}$.) agenicity of EAC cells.

\begin{tabular}{cccc}
\hline Groups & $\begin{array}{c}\text { Antioxidant } \\
\text { enzymes }\end{array}$ & $\begin{array}{c}\text { Catalase activity } \\
\text { (U/mg protein) }\end{array}$ & $\begin{array}{c}\text { Malondialialdhyde } \\
\text { (nmol/mg protein) }\end{array}$ \\
\hline 1 & & $56.00 \pm 0.40^{\mathrm{d}}$ & $20.50 \pm 0.25^{\mathrm{d}}$ \\
2 & $40.45 \pm 0.80^{\mathrm{c}}$ & $17.80 \pm 0.60^{\mathrm{c}}$ \\
4 & $81.20 \pm 1.85^{\mathrm{b}}$ & $42.30 \pm 1.50^{\mathrm{b}}$ \\
5 & $71.35 \pm 0.90^{\mathrm{b}}$ & $28.75 \pm 0.65^{\mathrm{a}}$ \\
6 & $73.50 \pm 1.10^{\mathrm{b}}$ & $30.60 \pm 0.45^{\mathrm{a}}$ \\
7 & $60.15 \pm 1.40^{\mathrm{b}}$ & $32.40 \pm 0.55^{\mathrm{a}}$ \\
8 & $63.80 \pm 0.55^{\mathrm{b}}$ & $35.10 \pm 0.60^{\mathrm{a}}$ \\
9 & $59.45 \pm 0.60^{\mathrm{d}}$ & $24.65 \pm 0.50^{\mathrm{d}}$ \\
10 & $61.90 \pm 0.75^{\mathrm{d}}$ & $26.70 \pm 0.65^{\mathrm{d}}$ \\
11 & $54.90 \pm 0.70^{\mathrm{d}}$ & $18.50 \pm 0.25^{\mathrm{d}}$ \\
12 & $56.15 \pm 0.45^{\mathrm{d}}$ & $20.35 \pm 0.30^{\mathrm{d}}$ \\
13 & $69.30 \pm 0.75^{\mathrm{c}}$ & $35.60 \pm 0.80^{\mathrm{c}}$ \\
14 & $71.90 \pm 1.30^{\mathrm{c}}$ & $38.40 \pm 1.10^{\mathrm{c}}$ \\
15 & $66.30 \pm 0.80^{\mathrm{d}}$ & $33.60 \pm 0.40^{\mathrm{d}}$ \\
\hline
\end{tabular}

Mean within the same column carrying different superscripts are significant $(\underline{\mathrm{P}<0.01)}$.

In mice, supplementation with curcumin provided significant antioxidant effects. Curcumin may decrease the production of free radicals which could lead to decreasing hepatic antioxidant enzyme activities catalase, glutathione peroxidase and glutathione reductase in all groups treated with AgNPS (3-15) that resulted in a significant reduction in lipid peroxidation.

Regarding to the histopathological changes there were several in the mice liver revealed that the inflammatory phase begun within 5 8 days after EAC cells implantation while the proliferative phase showed fibroblast proliferation and granulation tissue (Fibrovascular) formation at the $8^{\text {th }}$ day and the remodulation phase revealed scar formation with rearrangement of regenerated hepatocyte at the sometime and preimplantation of AgNPS 15 days and enhances of repithelization. The positive control mice liver were implanted with EAC cells revealed that focal coagulative necrosis of the hepatic parenchyma with various degenerative changes varied from cloudy swelling to hydropic degeneration. This hepatic capsule (protenitis) could be seen with numerous newly formed bile ductules in portal area (Fig. 1-4) in agreement with [32]. The liver of mice implanted with EAC cells and treated with 100 $\mu \mathrm{M}$ AgNPS at the same time revealed hepatic cells suffered from reversible hydropic degeneration with interstitial mononuclear cells infiltration and kuffer's cells usually appear hyperplasia. 

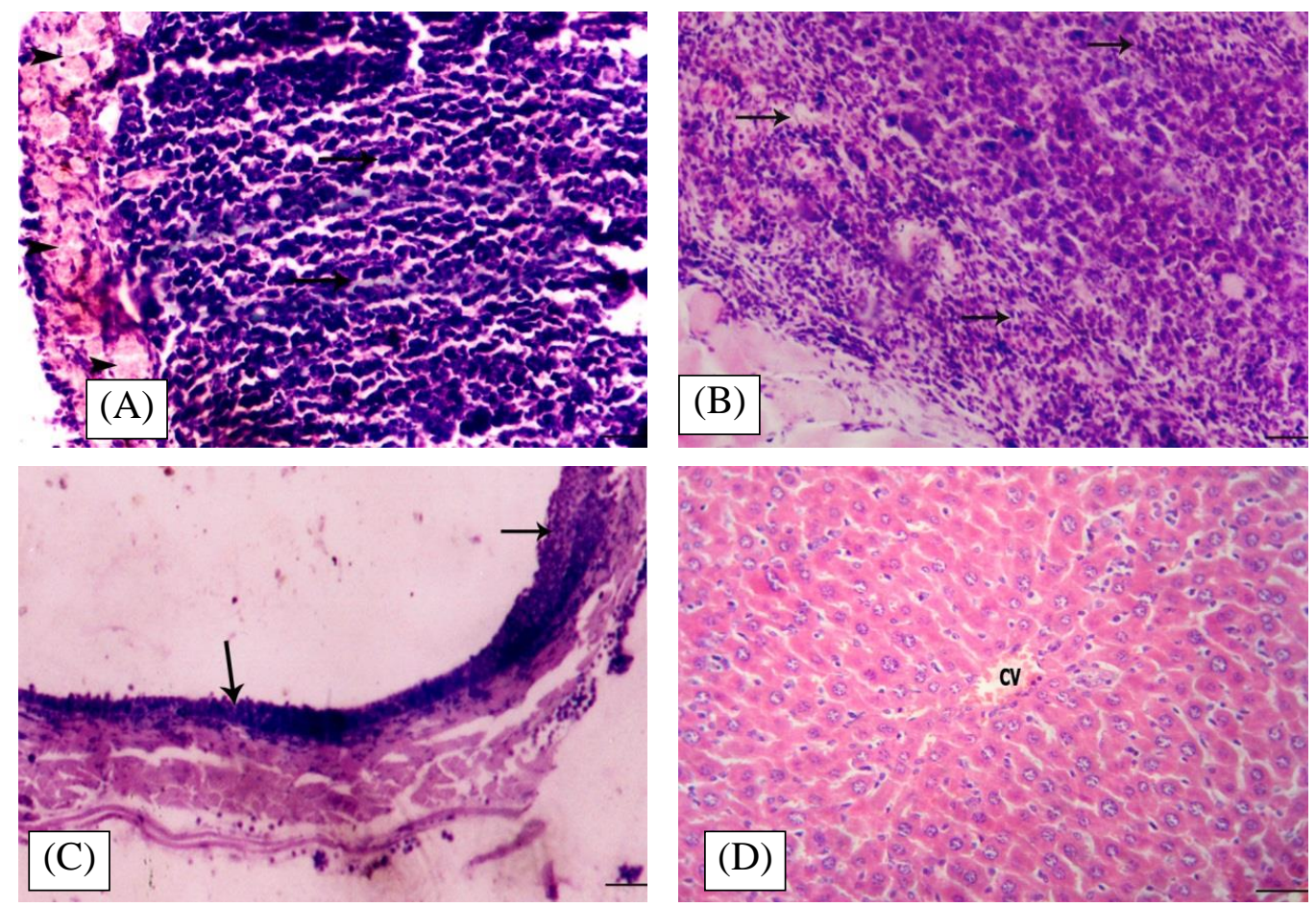

Figure $1 \mathrm{~A}$. Liver of mice implanted with EAC cell and treated with $100 \mu \mathrm{M}$ AgNPs at the same time revealed hepatic cells suffered from reversible hydropic degeneration with interstitial mononuclear cell infiltration. Kupffer's cells usually appear hyperplasia. (Negative control, bar $=100 \mu \mathrm{M})(\mathrm{H} \& \mathrm{E})$. B. Liver of mice implanted with EAC cell and treated $100 \mu \mathrm{M}$ AgNPs at the same time and curcumin $(400 \mathrm{mg} / \mathrm{kg})$, the hepatic blood vessels and sinusoids showed slight congestion, cloudy swelling and hydropic degeneration were common. C. Liver of mice implanted with EAC cells and treated $100 \mu \mathrm{M}$ AgNPs before implantation and curcumin 15 days before appeared interstitial and portal leucocytic aggregation mainly lymphocyte with normal hepatic cells. Hyperplastic kupffer's cells and mild congestion of the blood $(B a r=100 \mu M)(H \& E)$.

D. Liver of mice implanted with EAC cells and treated with $100 \mu \mathrm{M}$ AgNPs after implantation 8 days revealed lymphocyte with karyo and cytomeggally besides extramedullary hematopoiesis. $(\mathrm{Bar}=100 \mu \mathrm{M})(\mathrm{H}$ \& E).

\section{Conflict of interest}

The authors declare that they have no conflict of interest

\section{References}

[1] Wijnhoven S.W.P., Peijnenburg, W.J.G.M., Herberts, C.A., Hagens, W.I., Oomen, A.G., Heugens, E.H.W., Roszek, B.1, Bisschips, J., Gosens, I., Van De, D., Dekkers, S., De Joung, W.H., Van Zijverden, M., Sips, A.J. and Geertsma R.E. (2009): Nano silver a review of available data and knowledge gaps in human and environmental risk assessment. Nanotoxicology, 3(2):109138.

[2] Kim, J.S., Kuk, E., Nam, K., Kim, J.H., Park, S.J., Leo, H.J., Kim, S.H., Park, Y.K., Park, Y.H., Hwang, C.Y., Kim, Y.S.
Jeong, D.H. and Cho, M.H. (2007): Antimicrobial effects of silver nanoparticles in human hepatoma cells. Toxicol. In vitro, 23:1076-1084.

[3] Ghosh, S.S., Massey, H.D., Krieg, R. and Fazelbhoy, Z.A. (2009): Curcumin ameliorates renal failure in 5/6 nephrectomized rats: the role of inflammation. Am. J. Physiol. Renal. Physiol., 296: 1146-1157.

[4] Ahmed, M., Alsalhi, M.S. and Siddiqui, M.K.J. (1010a): Silver nanoparticle application and human health. Clinica. Chimica. Acta., 411:1815-1848.

[5] Rai, M., Yadav, A. and Gade, A. (2009): Silver nanoparticles as a new generation of anti-microbials. Biotechnol. Adv, 27:76-83. 
[6] Kildeby, N.L., Andersen, O.Z., Roge, R.E., Larsen, T., Petersen, R. and Riis, J.F. (2005): Silver nanoparticle (Research project). Aalborg University Faculty of Physics and Nanotechnology, 1-80.

[7] Gavanji, S., Shams, M., Shafagh, N., Jalali Zand, A., Larki, B., Doost Mohammadi, M., Taraghian, A.H. and Nikanezhad, S.V.(2012): Destructive effect of silver nanoparticles on biocontrol agent fungi trichoderma viride and $\mathrm{T}$. harzianum. CJASR 1(12): 83-90.

[8] Ahmed, M., Karns, M., Goodson, M., Rowe, J., Hussain, S., Schlager, J. and Hong, Y. (2008): DNA damage response to different surface chemistry of silver nanoparticles in cultured A549 cells. Toxicology 283, 101-108.

[9] Balbus, J.M., Maynard, A.D., Colvin, V.L., Castranova, V., Daston, G.P. and Denison, R.A. (2007): Meeting report: Hazard assessment for nanoparticles -report from an interdisciplinary workshop. Environ. Health. Perspect., 115:1654-1659.

[10] Hussain, S.M., Hess, K.L., Gearhart, J.M. Geiss, K.T. and Schlager, J.J. (2005): In vitro toxicity of nanoparticles in BRL 3A rat liver cells. Toxicol. In vitro, 19, 975983.

[11] Foldbjerg, R.; Dang, D.A. and Autrup, H. (2011): Cytotoxicity and genotoxicity of silver nanoparticles in the human lung cancer cell line, A549. Arch. Toxicol., 85(7):743-750

[12] Zhan, H., Suzuki, T., Aizawa, K., Miyagawa, K. and Nagai, R. (2010): Atazia telangiectasia mutated (ATM)mediated DNA damage response in oxidative stress -induced vascular endothelial cell senescence. J. boil. Chem., 285: 29662-29670.

[13] Guntupalli, M.M.R., Chandana, V.R., Palpu, P. and Annie, S. (2006): Hepatoprotective effects of rubiadin, A major constituent of rubia cordifolia linn, Journal of Ethnopharmacology 103,484490.

[14]Jaeschke, H., Williams, C.D., McGill, M.R. and Farhood, A. (2010): Herbal extracts as hepatoprotectants against acetaminophen hepatotoxicity. World J. Gastroenterol. 16, 2448-2450.

[15] Ghosh, S., Kaushik, R., Nagalakshmi, K., Hoti, S.L., Menezes, G.A., Harish, B.N. and Vasan, H.N.(2010): Antimicrobial activity of highly stable silver nanoparticles embedded in agar-agar matrix as a thin film. Carbohydr. Res., 345:2220-2227.

[16] Carmen, A. and Menedez, J.C. (2008): Some general remarks about cancer and cancer chemotherapy in Medicinal Chemistry of Anticancer Drugs, 152-160.

[17]Gottesman, M., Fojo, T. and Bates, S. (2002): Multidrug resistance in cancer: role of ATP-dependent transporters. Nature Reviews Cancer, 2: 48-58.

[18]Nygren, P. and Larsson R. (2003): Overview of the clinical efficacy of investigational anticancer drugs. J. Intern. Med., 253(1):46-75.

[19] Zeinab, E. H. (2009): Ginger extract antimutagenes as cancer chemopreventive agent against Ehrlich ascites carcinoma. Academic Journal of Cancer Research, 2(2):61-67.

[20] Oberdorster, G., Stone, V. and Donaldson, K. (2007): Toxicology of nanoparticles: a historical perspective Nanotoxicology. 1:2-25.

[21] Tirkey N., Kaur G., Vij G. and Chopra K. (2005): Curcumin a diferuloylmethane, attenuates cyclosporine induced renal dysfunction and oxidative stress in rat kidneys. J. biosc., 22(2):233-46.

[22] Gulrajani, M.L., Gupta, D., Periyasamy, S., and Muthu, S. (2008): Preparation and application of silver nanoparticles on silk for imparting antimicrobial properties. J. Appl. Polymer. Sci., 108:614-623.

[23] Bar-Ilan, O., Albrecht, R.M., Fako, V.E. and Furgeson, D.Y. (2009): Toxicity assessment of multisized gold and silver nanoparticles in zebrafish embryos, small, 5, 1897-1910.

[24] Takenaka, S., Karg, E., Roth, C., Schulz, H., Ziesenis, A., Heinzmann, U., Schramel, P. and Heyder, J. (2001): Pulmonary and systemic distribution of 
inhaled ultrafine silver particles in rats Environ. Health Persp.109 (suppl. 4) 547551.

[25] Hagihara, M.; Nishigaki, I.; Maseki, M. and Yagi, K. (1994): Age-dependent changes in lipid peroxide levels in lipoprotein fractions of human serum. J. Gevontol., 39:269-272.

[26] Cartes-Wanstreet, M.M.; Giedzinski, E.; Limoli, C.L. and Luderer, U. (2009): Over expression of glutamate- cysteine protects human COV434 granulosa tumor cells against oxidative and gamma-radiationinduced cells death. Mutagenesis, 24: 211224.

[27]Hendi, A. (2010): Silver nanoparticles mediated differtial response in some of liver and kidney functions during skin would healing. J. King Saud Univ. Sci., 40(5):47-52.

[28] Czeezt, N.; Stolle, S. and Sheshde R.A. (2016): Glutatione level and glutathione dependent activities in blood serum of patients with gastrointestinal tract tumors. Clin. Biochem., 260(1):32-38.

[29] Wills, E.D. (1966): Mechanisms of lipid peroxide formation in animal tissues. Biochem. J., 99:667-676.

[30] Naghsh, N.; Noori, A.; Aqababa, H. and Amirkhani-Dehkordi, S. (2012): Effects of Nano-silver particles on alanine amino transferase (ALT) activity and white blood cells (WBC) level in male wistar rats, in vivo condition. Zahedan J. Res. Med. Sci., (ZJRMS), 14(7):34-37.

[31] Doudi, M. and Setorki, M. (2014): Acute Effect of Nano-silver to Function and tissue live of mice after $\mathrm{I} / \mathrm{P}$ infection. $\mathrm{J}$. Biolo. Sci., 14 (3): 213.

[32] Biase, L.A.; Warnau, D. and Zhou, S. (2016): Oxidative stress and oxidative damage in chemical carcinogenesis. Toxicol. App. Pharmacol., (13):131-139.



دراسة التأثيرات النانونية لسمية جزيئات الفضة النانوية كمضاد للسرطان وعلاجها بالكركم$$
\text { مجدى فكرى ابو الفتوح ، على حيدر ابو حديدو اسر اء غريب قطب }
$$$$
\text { قسم الطب الشرعى و السموم ـ كلية الطب البيطري ـ جامعة الزقازيق }
$$

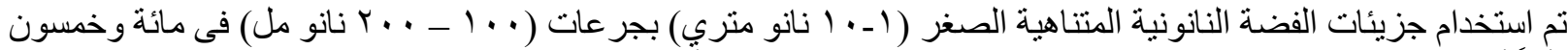



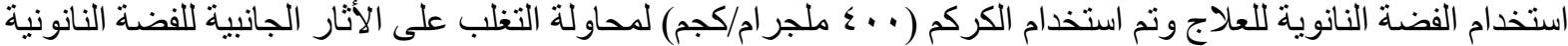

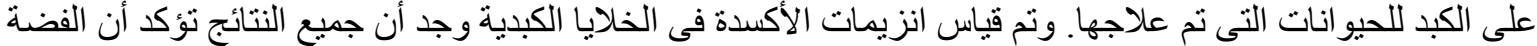

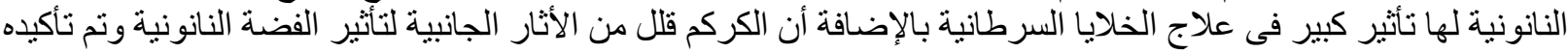
عن طريق تحليل الإنزيمات الكبدية (MDA, CAT, GSH, GR, GPx)
} 